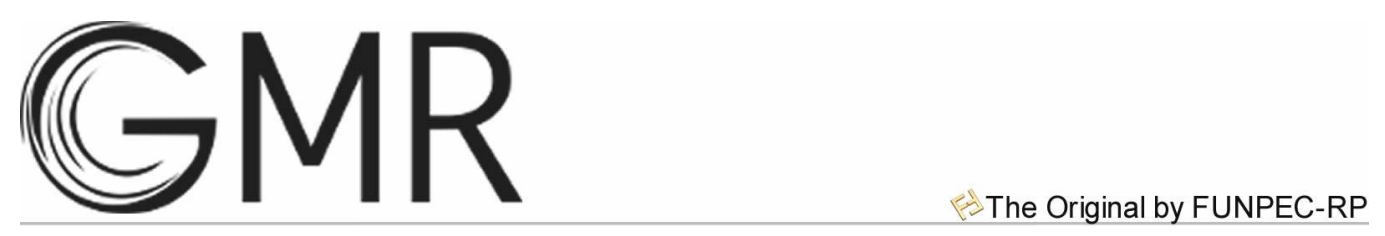

\title{
Attenuation of lead genotoxicity in Glycine max by adsorbent nanosized titanium dioxide using phenotypic, cytogenetic and DNA status bioassays
}

\author{
E. Abdelhaliem ${ }^{1}$ and J. Al-Shalawi ${ }^{2}$ \\ ${ }^{1}$ Plant Cytogenetics and Molecular Genetics, Botany and Microbiology \\ Department, Faculty of Science, Zagazig University, Sharkia, Egypt \\ ${ }^{2}$ Biology Department, Faculty of Science, Princess Nourah Bint \\ Abdulrahman University, Riyadh, Saudi Arabia \\ Corresponding author: E. Abdelhaliem \\ E-mail: ekram.esa@gmail.com
}

Genet. Mol. Res. 18 (3): gmr18350

Received May 07, 2019

Accepted July 13, 2019

Published July 30, 2019

DOI http://dx.doi.org/10.4238/gmr18350

\begin{abstract}
Genotoxicity caused by heavy metals can negatively affect vital processes of crop plants, though remedial measures can be used to reduce such damage. We examined the possible stimulatory and phytotoxicity impacts of three nanosized titanium dioxide $\left(\mathrm{nTiO}_{2}\right)$ doses on soybean (Glycine max) and how adsorption of lead $(\mathrm{Pb})$ onto the surface of $\mathrm{nTiO}_{2}$ may attenuate the toxic action of $\mathrm{Pb}$ on soybean by comparing the toxicity of three $\mathrm{Pb}$ doses before and after the adsorption process. The exposure time was $48 \mathrm{~h}$. Phenotypic parameters (seedling growth, phytotoxicity, tolerance and vigor indices), cytogenetic tests of pollen grain performance, and DNA status (using flow cytometry, comet assays and analysis of RAPDs) were used as bioassays to assess the effect of the treatments. The optimal $\mathrm{nTiO}_{2}$ dose was $10 \mathrm{mg} . \mathrm{L}^{-1}$ because it i) stimulated and accelerated seedling development parameters, fertility and germination of pollen grains, ii) increased nuclear DNA content and decreased the extent of DNA damage, and iii) generated the maximum number of amplified DNA bands as an indicator for appearances of new DNA bands (genes) more than the control. Doses of $\mathrm{nTiO}_{2}$ higher and lower than the optimal dose resulted in a gradual decline in these parameters, especially the higher dose. The three
\end{abstract}


doses of $\mathrm{Pb}$ induced notable inhibitory and genotoxic impacts on all biomarkers used, in a dose-dependent manner. We conclude that the powdered state of optimal dose $(10 \mathrm{mg})$ had a good ability to adsorb $\mathrm{Pb}$ onto its surface and consequently mitigated its toxicity. This was evident through the significant amelioration of parameters of each biomarker after application of the three $\mathrm{Pb}$ adsorbate solutions on soybean seeds. Therefore, we suggest that stimulatory and adsorbent $\mathrm{nTiO}_{2}$ dose may be used in the future to protect against heavy metal toxicity in economically important plants.

Key words: Adsorption process; Heavy metals; Nanoparticals; Soybean; Pollen grain performance; DNA bioassays

\section{INTRODUCTION}

Higher plant bioassays can detect a wide range of genetic damage, including gene mutations, chromosome damage, and DNA damage analysis. (Maluszynska and Juchimiuk, 2005; Iqbal et al., 2019). One of these studied plants, Glycine max (soybean), belongs to the family Leguminosae and has a diploid chromosomal set $(2 n=40)$. The study of Blanco et al. (2017) demonstrated that soybean crops can incorporate and accumulate more potentially toxic metals, such as lead, than numerous other crops because of its high biomass and easy cultivation. It is used as a model plant material and suggested a preliminary screening test for genotoxic agents and environmental mutagens due to it has large number of genetic markers and/or database and are also highly suitable for testing the genotoxic agents (Vig, 1982).

In recent years, environmental pollution by heavy metals has significantly increased due to industrial, motor vehicle, agricultural, chemical fertilizer, geogenic, domestic effluent, pharmaceutical, and atmospheric sources. Therefore, the impact on ecological and global public health has been an increasing concern. Lead $(\mathrm{Pb})$ is an anthropogenic pollutant and one of the most toxic heavy metals present in the environment known to pollute agricultural lands and consequently economical crop plants, even at low doses (Nas and Ali, 2018). They reported that $\mathrm{Pb}$ cause oxidative damages of protein and DNA by over production of reactive oxygen species ROS, which in turn may cause genotoxicity to plant cells. The excessive accumulation of lead in plant tissue not only strongly inhibits various vital growth processes such as seed germination and seedling development parameters but also DNA synthesis, pollen grains fertility and seed productivity (Pourrut et al., 2011). The effects of lead on DNA occur directly or indirectly, resulting in DNA damages leading to destabilization of the double helical structure of DNA, mismatches of the bases on nucleic acids, single-nucleobase lesions on DNA, single DNA strand breaks, and double DNA strand breaks and thereby affects horizontal DNA-DNA or DNA-protein links (Nas and Ali, 2018). The study of Pourrut et al. (2011) reported that lead may enter the nucleus and bind directly or indirectly to the DNA, causing disruption of DNA repair and replication mechanisms. They also evaluated DNA damage induced by lead in Vicia faba using comet assay and demonstrated that the genotoxic effects of lead (DNA breakage and micronucleus formation) may result from the overproduction of ROS induced by lead. 
Alternative strategy has been developed in order to reduce or ameliorate genotoxic effects of lead $(\mathrm{Pb})$ on plant DNA. Fortunately, heavy metal ion speciation might be altered by nanoparticles (especially oxide NPs) as adsorbing pollutant agents, owing to their higher surface area and more active surface sites that can neutralize or reduce the toxic effects of heavy metals by changing their transport and bioavailability in natural systems (Bok-Badura et al., 2018). From these oxide NPs, nanosized titanium dioxide $\left(\mathrm{nTiO}_{2}\right)$ has been shown to aggregate and adsorb heavy metals on their surface as result of their remarkably high surface area, their photocatalysis ability, their aggregation behavior, their photocatalysis ability, their strong adsorption capacity and the presence of high affinity surface hydroxyl groups, and consequently, reduce their bio-availability and alter their toxic effects on plants (Bok-Badura et al., 2018). $\mathrm{nTiO}_{2}$ has been used as an adsorbent material for the removal of heavy metals from water (Poursani et al., 2016). For example, the study of Yang et al. (2012) demonstrated that $\mathrm{nTiO} 2\left(\mathrm{nTiO}_{2}\right)$ could reduce the free $\mathrm{Cd}^{2+}$ in toxic media, further lowering its bioavailability and toxicity to a green algae, Chlamydomonas reinhardtii.

Nanosized $\mathrm{TiO}_{2}$ has been tested for its positive and stimulating potential on plants by promoting and improving seed germination and crop performance, especially at the appropriate dose due to its ability to penetrate the seed coat, resulting in increased water/nutrient absorption (Marchiol et al., 2016; Lyu et al., 2017). Only recently, the genetic implications of nanoparticle-induced positive changes have been validated through investigations on positive changes in gene expression, enhanced mRNA expression and protein level in spinach by nano- $\mathrm{TiO}_{2}$ (Gao et al., 2006; Kole et al., 2013), indicating their potential use in crop improvement. This positive impact was linked with enhanced activities of enzymatic antioxidants, as well as reducing oxidative damages of DNA. The potential positive effects of $\mathrm{nTiO}_{2}$ may provide a helpful approach for reducing the consumption of chemicals through agriculture by alleviating heavy metal environmental pollution.

On the contrary, $\mathrm{nTiO} 2$ at high doses can induce phytotoxicity and exhibit a negative impact on seed germination and plant growth (Feizi et al., 2013). The study of Ruffini Castiglione et al. (2014) concluded that plants can be harmed by $\mathrm{TiO}_{2}-\mathrm{NPs}$ at high doses with influence on mitotic index and induced genotoxic effects, DNA fragmentation and reactive oxygen species (ROS) during its reaction with DNA.

It is important for detection of genotoxicity of various types of genotoxic agents on exposed and/or non-exposed crop plants, to understand the biological consequences of DNA damages and their molecular modes of action that lead to alterations or repair the genetic material by introducing number of bioassays that are commonly used to provide robust and reliable assessment of nuclear DNA damage in economic crop plants (Maluszynska and Juchimiuk, 2005). Some of the recent bioassays were flow cytometry, comet assay, and random amplified polymorphic DNA (RAPD).

DNA damage in germ cells (pollen mother cells and pollen grains) induced by accumulative genotoxicity and chromosomal aberrations can lead to heritable damage in subsequent generations, causing a reduction in fertility and vigor, seed yield, and quality of economic crop plants (Abdelhaliem et al., 2013). Therefore, pollen grains performance should be estimated as a useful tool to assess the biological effect of any genotoxic agent.

Recently, molecular cytogenetic techniques were introduced to allow analysis of genotoxicity, both at the chromosomal and nuclear DNA level (Maluszynska and Juchimiuk, 2005). Flow cytometry methodology (FCM) is a fast and accurate technique that has been tested theoretically with a number of different plant species for estimation minute 
changes in nuclear DNA content (nDNA) and genome size, the gain or loss of a single chromosome chromosomal, DNA damage, and chemical adducts to DNA and DNA strand breakage to assess genotoxicity due to different genotoxic and mutagenic agents (Monteiro et al., 2010).

The comet assay, an alkaline version of the single-cell gel electrophoresis is another good and a new technique for assessing genotoxicity in eukaryotic plant cells because of its simplicity, quickness and sensitivity for the detection of various DNA lesions including strand breaks, base damage and alkali-labile sites in individual cells, induced by a variety of genotoxic agents (Bhat et al., 2011). The study of Rodriguez et al. (2011) compared the validity of the comet assay and FCM in evaluating genotoxicity tests in plants and demonstrated that the data provided by both techniques complement each other and presented high correlation in the detection of DNA damage.

On the other hand, the RAPD fingerprinting technique, a PCR-based molecular marker technique, is a fundamental tool, being a simple, rapid, and low-cost assay used to detect genotoxins that induce a wide range of DNA damage to plants (point mutations, inversions, deletions). It can also be used to describe similarities and diversification between samples by the appearance of new unique bands, disappearance of polymorphic bands, and variation in band intensities (Abdelhaliem and AL-Huqail, 2016; Pal, 2016)

Taking the above into consideration, the present study aimed: 1) to evaluate possible stimulatory or inhibitory influences of $\mathrm{nTiO}_{2}$ as well as phytotoxicity of heavy metal lead $(\mathrm{Pb})$ on soybean seeds; 2 ) to test the efficiency of the stimulatory (optimal) dose of $\mathrm{nTiO}_{2}$ as an adsorbent material to neutralize and alleviate the phytotoxic action of lead on economic crop plant soybean, and; 3) to apply $\mathrm{nTiO}_{2}$ in agriculture for protection of economic crops and to increase agricultural production in future.

\section{MATERIAL AND METHODS}

\section{Plant material}

Soybean seeds (Glycine max variety "Hodgson") were obtained from the King Saud University, College of Food Science and Agriculture, Department of Plant Production, Riyadh, Saudi Arabia. Fresh and healthy uniformly sized seeds were divided into four groups. Seeds of each group were surface sterilized in a $1 \% \mathrm{v} / \mathrm{v}$ solution of sodium hypochlorite by gentle magnetic stirring for $10 \mathrm{~min}$, then rinsed three times with deionized water and air dried. The first group of seeds did not receive any further treatment to serve as the control. The second group was treated with $\mathrm{Pb}\left(\mathrm{NO}_{3}\right)_{2}$ solutions, the third group with $\mathrm{nTiO}_{2}$, and the fourth group was treated with $\mathrm{Pb}$ adsorbate solutions after adsorption process.

\section{Preparation of lead nitrate solutions}

White powdered lead nitrate (purity: 99\%, molecular weight 331.20; Sigma Chemical Co., Sigma, MO, USA), was used in this study. The experimental treatments included three doses $\left(75,100\right.$, and $\left.150 \mathrm{mg} . \mathrm{L}^{-1}\right)$ that were freshly prepared by dissolving $\mathrm{Pb}\left(\mathrm{NO}_{3}\right)_{2}$ in deionized water and adjusting their $\mathrm{pH}$ to 5.5 with $\mathrm{HNO}_{3}$ before being used as treatments for soybean seeds. These doses were in the range between doses reported in 
other studies [doses were in the range between doses reported in other studies as (Oladele et al., 2014)]. Distilled water was used as an untreated control (without Pb).

\section{Preparation of $\mathrm{nTiO}_{2}$ suspension}

Fine-particulate nTiO2 (AEROXIDE® $\mathrm{TiO}_{2} \mathrm{P} 25$, Sigma Chemical Co., Germany), had a high specific surface area of $35-65 \mathrm{~m}^{2} \cdot \mathrm{g}^{-1}$; average primary particle size, $21 \mathrm{~nm}$, and; purity, $\geq 99$. $\mathrm{nTiO}_{2}$ was suspended directly in filter-sterilized double distilled water. Small magnetic bars were placed in the suspension to stir and avoid aggregation followed by sonication on ice by ultrasonic vibration at $450 \mathrm{~W}, 40 \mathrm{kHz}$ (UP100H Ultrasonic processor, Hielscher Ultrasound Technology, Germany), for $30 \mathrm{~min}$ and vigorous vortexing to obtain homogeneous suspensions ( $5 \mathrm{~min}$ ), when required. A triplicate hydroponic experiment was conducted to determine the positive and negative effects of the three $\mathrm{nTiO}_{2}$ doses $(5,10$, and $20 \mathrm{mg} . \mathrm{L}^{-1}$ ) on soybean seeds.

The selected doses were in the range between doses reported in other studies (Feizi et al., 2013) and distilled water (DI) without $\mathrm{nTiO}_{2}$ was used as control. To better understand the characters of the selected nanosized titanium dioxide $\left(\mathrm{nTiO}_{2}\right)$, the current study used transmission electron microscope (TEM) (JEOL JEM-2010, Japan, operated at $80 \mathrm{kV})$.

\section{Characterization of $\mathrm{TiO}_{2}$ in dispersion solutions}

The $\mathrm{TiO}_{2}$ nanoparticle suspension was characterized for size and dispersity. Laser doppler velocimetry (LDV) was performed using a Malvern Nanosized-ZS ZEN3600 (Worcestershire, United Kingdom) for the characterization of zeta potential. The particle size distributions were determined based on number, volume, and scattering intensity.

\section{Treatments of soybean seeds}

Viability and uniformity in size soybean seeds were used in this study. A batch hydroponic experiment was conducted in triplicate to determine the effects of $48 \mathrm{~h}$ exposure of $\mathrm{nTiO}_{2}\left(5,10\right.$, and $\left.20 \mathrm{mg} . \mathrm{L}^{-1}\right)$ and $\mathrm{Pb}\left(75,100\right.$, and $\left.150 \mathrm{mg} . \mathrm{L}^{-1}\right)$ doses on seedling growth parameters of soybean seeds, alongside the control. Twenty surface-sterilized soybean seeds were placed on sterilized petri dishes and soaked in $30 \mathrm{~mL}$ of each dose of $\mathrm{nTiO}_{2}$ or $\mathrm{Pb}$ alongside untreated samples under the laboratory conditions. The solution level was maintained to avoid changes in exposure dose. After all treatments, treated and untreated soybean seeds were washed three times with distilled water and used for analyses by different bioassays.

\section{Phenotypic parameters of soybean seedling growth, phytotoxicity, tolerance, and vigor indices}

After all treatments, each replicate (corresponding to treated and untreated soybean seeds) was washed three times with distilled water and sown immediately in earthenware pots (30 $\mathrm{cm}$ high x $20 \mathrm{~cm}$ diameter) containing soil obtained from topsoil in the field and grown in a greenhouse for 35 days until reaching the seedling stage. 
Triplicates of 10 seedlings were randomly sampled, and the following seedling growth parameters were recorded: mean lengths $(\mathrm{cm})$ of root, shoot, and seedlings. The percentage phytotoxicity of shoot and root of seedlings was calculated following the formula given by Mishra and Choudhuri (1999). The mean root/ shoot ratios, leaf parameters (based on the number of leaves per plant), leaf surface area $\left(\mathrm{cm}^{2}\right)$, and dry weight ( $\mathrm{g}$ ) of root and shoot systems were also measured. The tolerance index (TI) and seedling vigor index (VI)I were computed based on the study of Vashisth and Nagarajan (2010) as shown in the following four equations:

\footnotetext{
$\%$ Phytotoxicity of root $=$ Root length of control - Root length of treatment $\times 100 \quad$ (Eq. 1)

$\%$ Phytotoxicity of shoot $=$ Shoot length of control - Shoot length of treatment $\times 100 \quad$ (Eq. 2$)$

Tolerance index $(\mathrm{TI}) \%=$ Root length of treatment $/$ Root length of control $\times 100 \quad$ (Eq. 3)

Vigor index $(\mathrm{VI}) \mathrm{I}=$ Seedling length $(\mathrm{cm}) \times \%$ of Germination
}

\section{Cytogenetic analyses of pollen grains (PGs) of mature anthers}

Triplicates of treated and untreated soybean seedlings mentioned above left for 45 days until reached the flowering stage. Ten large-sized flower buds from ten plants for each treatment dose, plus the controls, were collected, then fixed immediately in Carnoy's fixative for $24 \mathrm{~h}$ and then stored in ethanol $(70 \%, \mathrm{v} / \mathrm{v})$ at $4^{\circ} \mathrm{C}$ until they were used for cytogenetic analyses of the pollen grains. Finally, mature anthers containing PGs were stained using alcoholic hydrochloric acid-carmine smear for one week as described in the study of Abdelhaliem et al. (2013). PGs anomalies were examined using certain PGs parameters. PGs which took red stain and had a regular outline were considered as fertile, while empty and unstained (colorless) ones were sterile (Abdelhaliem et al., 2013). The following PGs parameters were recorded: the final percentage of morphological homogeneity (MH) and absolute pollen viability (APV) were calculated using the formula used by Tosun and Koyuncu (2007) while and Pollen germination (PGs) percentage was calculated according to (Visser et al., 2007) as shown in the following equations:

The final percentage of morphological homogeneity $(\mathrm{MH})$ :

$$
\mathrm{MH} \%=\frac{(\text { No.of normal shaped PGs) }- \text { (No.of aborted PGs) }}{\text { total number of pollen field }} \times 100
$$

Absolute pollen viability (APV):

$$
\mathrm{APV} \%=\frac{\% \text { stained PGs } \times \% \text { Germinated PGs }}{100}
$$

Germination percentage of PGs :

$$
\text { Pollen germination } \%=\frac{\text { No.of germinated PGs }}{\text { Total No.of PGs }} \times 100
$$

\section{Molecular cytogenetic biomarkers for detection DNA status}

Treated and untreated soybean seeds with $\mathrm{nTiO}_{2}, \mathrm{~Pb}$, and $\mathrm{Pb}$ adsorbate solutions were used instead of leaves in this study to avoid the accumulation of staining inhibitors within leaves (Sliwinska et al., 2009). 


\section{Estimation of variation in nuclear DNA content and genome size by flow cytometry}

Nuclear DNA content and genome size of soybean nuclei were estimated using a rapid and simple protocol as described by Arumuganathan and Earle (1991). Fifty mg of germinated soybean seeds were chopped into $<0.5 \mathrm{~mm}$ pieces on ice using a sharp razor blade after adding $1 \mathrm{~mL}$ of solution A (14.3 mL $\mathrm{MgSO}_{4}$ buffer (ice-cold), $15 \mathrm{mg}$ dithiothreitol (Sigma, D-0632), $300 \mu \mathrm{L}$ fluorochrome stain, propidium iodide (PI) stock, and $375 \mu \mathrm{L}$ Triton X-100 stock) in plastic petri dishes. The pieces were then homogenized using a mortar for isolation of nuclei from treated and untreated seeds. The solution of homogenized nuclei was filtered through a nylon cloth $(50 \mu \mathrm{m}$ mesh size $)$, centrifugated at $15,000 \mathrm{~g}$ for 15 to $20 \mathrm{~s}$ and finally the supernatant discarded. The pellet was resuspended in $200 \mu \mathrm{L}$ of solution B ( $3 \mathrm{~mL}$ Solution A, 7.5 $\mu \mathrm{L}$ RNAase (DNAase free), $3.0 \mu \mathrm{L}$ of human leucocytes (HLN)). The relative fluorescence of nuclei was measured using flow cytometry which was conducted in the immunology laboratory at King Khalid Hospital. The measurements of relative fluorescence intensity of nuclei stained with propidium iodide (PI) was performed on a linear scale and, typically, at least 5000 nuclei were analyzed for each sample. The histogram of relative DNA content was obtained after flow cytometric analysis of stained nuclei of soybean. Fresh HLN $(2 \mathrm{C}=7.0 \mathrm{pg})$ served as internal standards for PI flow cytometric analysis. The analysis compared the mean position of the peaks due to soybean nuclei with the mean peak position of the internal standard. Fluorescence ratios $(2 \mathrm{C}$ DNA content/ sample, relative to the standard, were used to calculate DNA content (in picograms, pg) and genome size (in mega base pairs, Mbp) according to the following formulae used by Dolezel et al. (2003):

$$
2 \mathrm{C} \text { DNA content }(\mathrm{pg})=\frac{(\text { Sample Peak mean } \mathrm{x} \text { Standard DNA content }(7)}{\text { Standard Peak mean }}
$$

where: the symbol (C) (the DNA content of the haploid set of chromosomes) while the equivalent number of base pairs (genome size) was calculated assuming that $1 \mathrm{pg}$ DNA is equivalent to $0.965 \times 10^{9}$ bp or $965 \mathrm{Mbp}$ according to (Dolezel et al., 2003).

\section{Comet assay method for the detection of damage in the nuclear DNA of treated soybean}

Isolation of nuclei and single cell gel electrophoresis (Comet assay) were carried out and described as in the study of Abdelhaliem and Al-Huqail (2016).

\section{Isolation of nuclei}

After removal of the seed coat from embryonic tissues, the latter were placed in a small petri dish containing $200 \mu \mathrm{L}$ of cold $400 \mathrm{mM}$ Tris- $\mathrm{HCl}$ buffer, $(\mathrm{pH} 7.5)$ on ice. Using a razor blade, the seed was gently sliced into small pieces to release nuclei into the buffer under yellow light. Each slide was previously coated with $1 \%$ agarose. After heating to the normal melting point (NMP), the slide was dried and covered with a mixture of $55 \mu \mathrm{L}$ of nuclear suspension and $55 \mu \mathrm{L}$ of low melting point (LMP) agarose (1\% prepared with phosphate-buffered saline) at $40^{\circ} \mathrm{C}$ and sealed with a cover slip. The slide was placed on ice 
for at least $5 \mathrm{~min}$, and then the coverslip was removed. Then, $110 \mu \mathrm{L}$ of LMP agarose $(0.5 \%)$ was placed on the slide and coverslip was mounted again. After 5 min on ice, the coverslip was removed.

\section{Single cell gel electrophoresis (SCGE)}

The slides containing soybean nuclei were placed in a horizontal gel electrophoresis tank containing freshly prepared cold electrophoresis buffer $(300 \mathrm{mM}$ $\mathrm{NaOH}, 1 \mathrm{mM}$ EDTA, $\mathrm{pH}>13$ ) and incubated for $15 \mathrm{~min}$. Electrophoresis was performed at $16 \mathrm{~V}, 300 \mathrm{~mA}$ for $30 \mathrm{~min}$ at $4^{\circ} \mathrm{C}$. Then the gels were neutralized by washing three times in $400 \mathrm{mM}$ Tris- $\mathrm{HCl}(\mathrm{pH} \mathrm{7.5)}$ and stained with ethidium bromide $(20 \mu \mathrm{g} / \mathrm{mL}$ ) for $5 \mathrm{~min}$. After staining, the gels were dipped in ice-cold distilled water and immediately analyzed.

\section{Imaging and analysis software}

DNA damage in 50 randomly selected nuclei on each slide were analyzed and assessed qualitatively and quantitatively by visual scoring or by fluorescence microscopy with an excitation filter of $546 \mathrm{~nm}$, a barrier filter of $590 \mathrm{~nm}$, and a computerized CCD camera digital image analysis system (Komet Version 3.1. Kinetic Imaging, Liverpool, UK). Tail moment (TM, fraction of migrated DNA multiplied by some measure of tail length) became a common descriptor along with tail length $(\mu \mathrm{m})$ and percentage of DNA in the tail, tail DNA (TD\%, relative percentage of DNA in the comet tail), were used as parameters of DNA damage.

\section{RAPD- PCR for detecting damage in treated soybean DNA}

\section{Isolation of Genomic DNA}

Isolation of genomic DNA from untreated and treated germinated soybean seeds with $\mathrm{nTiO}_{2}, \mathrm{~Pb}$, and $\mathrm{Pb}$ adsorbate solutions were accomplished using the hexadecyl trimethyl ammonium bromide (CTAB) method as described in the study of Abdelhaliem and Al-Huqail (2016).

\section{RAPD-PCR analysis and agarose gel electrophoresis}

RAPD-PCR analysis and agarose gel electrophoresis were conducted as described in the study of Abdelhaliem and Al-Huqail (2016). A total of twenty random DNA oligonucleotide primers $(10$ mer) were independently used in the PCR reactions (UBC, University of British Columbia, Canada), with some modifications. Only four RAPD primers (P-12, 14, 15, and 19) succeeded to generate reproducible amplified DNA products.

\section{Band scoring and data analysis}


Analysis of RAPD bands based on alterations in the number of amplified DNA bands, their size, intensity as well as loss or gain of DNA bands were performed by Bio One D++ software (Vilber Lourmat, France). Any change observed in RAPD profiles of treated soybean DNA was scored. The presence and absence of each DNA band was determined by making a binary matrix ( 1 if present and 0 if absent) for each sample. Polymorphic DNA bands (unique and non-unique) and monomorphic bands were also scored. DNA polymorphism in RAPD biomarker profiles included the loss of a normal band and the appearance of a new band compared with the control samples were evaluated.

\section{Adsorption process}

\section{Preparation of $\mathrm{nTiO}_{2}$ adsorbent}

The powdered state $(10 \mathrm{mg})$ of positive and stimulatory $\mathrm{nTiO}_{2}$ dose $\left(10 \mathrm{mg} \cdot \mathrm{L}^{-1}\right)$ that called (optimal dose) was selected to be adsorbent dose based on its vigorous stimulatory action on phenotypical parameters (seedling growth) and fertility, germination and viability of soybean pollen grains. This was carried out for testing its adsorbent capacity to adsorb $\mathrm{Pb}$ onto its surface, which aimed to neutralize and minimize lead toxicity on soybean seeds.

\section{Preparation of $\mathrm{Pb}$ adsorbate solutions}

Adsorption of $\mathrm{Pb}$ onto the surface of powdered $\mathrm{nTiO}_{2}$ was carried out from the solutions of three $\mathrm{Pb}$ doses $\left(75,100\right.$, and $\left.150 \mathrm{mg} . \mathrm{L}^{-1}\right)$ which prepared and used previously.

\section{Absorption process}

Adsorption process was carried out according to (Pena et al., 2005) with some modifications. Three replicates of $10 \mathrm{mg}$ powdered $\mathrm{nTiO}_{2}$ was used as an adsorbent for each dose of $\mathrm{Pb}\left(75,100\right.$, and $\left.150 \mathrm{mg} . \mathrm{L}^{-1}\right)$ in separate $250 \mathrm{~mL}$ Pyrex glass Erlenmeyer flasks. The adjustment of the $\mathrm{pH}$ to $7 \pm 0.1$ in each flask was achieved by adding hydrochloric acid and sodium hydroxide at room temperature $\left(21-25^{\circ} \mathrm{C}\right)$. Samples were then stirred using a magnetic stirrer to mix for $24 \mathrm{~h}$. After that, the three flasks were shaken at $150 \mathrm{rpm}$ in a reciprocating shaker and kept in dark at $25 \pm 1{ }^{\circ} \mathrm{C}$ and then they were stirred in a VORTEX-Gene ${ }^{\mathrm{TM}}$ for $10 \mathrm{~s}$ and incubated for $2 \mathrm{~min}$ at room temperature. Then, the mixture was centrifuged twice for $35 \mathrm{~min}$ at 14,000 rpm using a high-speed centrifuge (Hermle Z323, Germany) and the supernatant (the liquid phase) was collected and named ' $\mathrm{Pb}$ adsorbate solution'.

\section{Treating soybean seeds with three $\mathrm{Pb}$ adsorbate solutions}

Under the laboratory conditions, a completely randomized design was conducted in triplicate to apply the three $\mathrm{Pb}$ adsorbate solutions on soybean seeds. 
Twenty fresh, healthy uniformly sized and surface sterilized soybean seeds were placed in sterilized petri dishes and soaked in $\mathrm{Pb}$ adsorbate solutions separately for $48 \mathrm{~h}$ alongside untreated seeds (control) which were exposed only to distilled water. All solutions were added to the Petri dishes and run at the same time. The treatment of $\mathrm{Pb}$ adsorbate solutions in addition to both treatments of $\mathrm{nTiO}_{2}$ and $\mathrm{Pb}$ were tested on soybean seeds at the same time alongside the control. All the same biomarkers and analyses used above for $\mathrm{nTiO}_{2}$ and $\mathrm{Pb}$ treatments were applied to the seeds treated with three doses of $\mathrm{Pb}$ adsorbate solutions compared to that of the equivalent $\mathrm{Pb}$ doses before adsorption.

\section{Statistical analyses}

Each experiment in this study was carried out in triplicate. The data obtained were expressed as means \pm standard deviation (SD) and statistically analyzed by using one-way ANOVA. The P-value level was set at 0.05.

\section{RESULTS AND DISCUSSION}

\section{Nanosized Titanium Dioxide characterization}

Figure 1 shows the TEM images of purified $\mathrm{nTiO}_{2}$ dispersion in the applied three doses at $\times 100,000$ magnification. TEM observation showed homogenous dispersion with fine particles at the $5 \mathrm{mg} . \mathrm{L}^{-1}$ and $10 \mathrm{mg} . \mathrm{L}^{-1}$ doses but with appropriate large size without any agglomerations. This is in contrast to the $20 \mathrm{mg} \cdot \mathrm{L}^{-1} \mathrm{nTiO}_{2}$ dose which was observed to have high levels of agglomerations with non-homogeneous dispersion. The zeta potential of the $\mathrm{nTiO}_{2}$ suspensions was determined and scored at $10.3,-10.8$, and $-5.01 \mathrm{mV}$ for $\mathrm{nTiO}_{2}$ doses 5,10 , and $20 \mathrm{mg} . \mathrm{L}^{-1}$, respectively (Figure 1D-F). The variation in zeta potential may be attributed to the dispersion of the three $\mathrm{nTiO}_{2}$ doses.
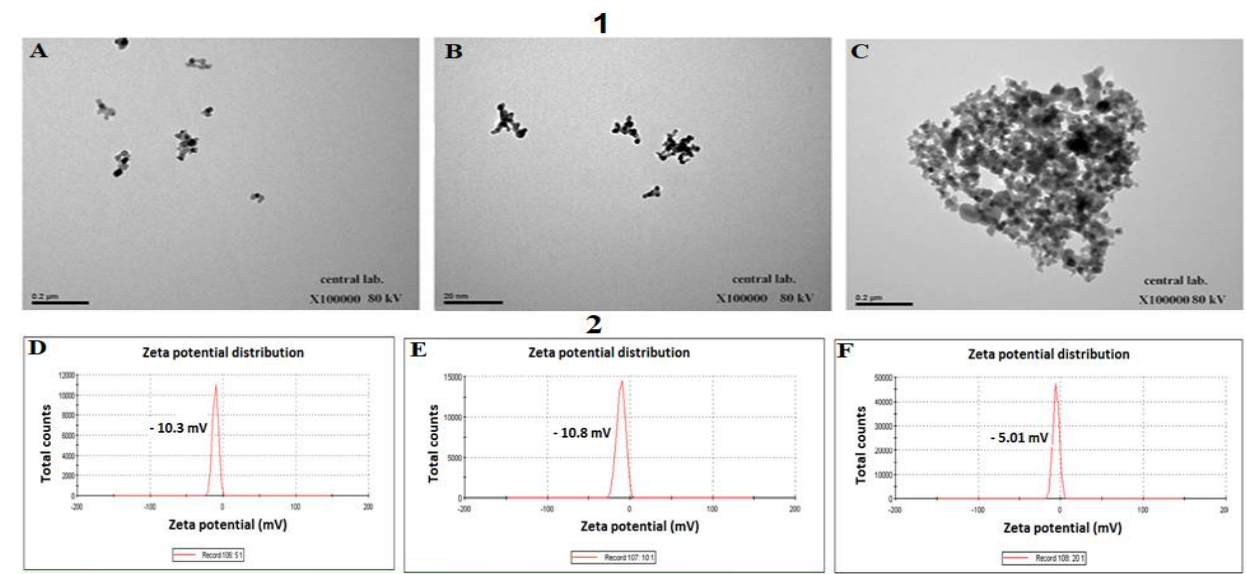

Figure 1. Characterization of $\mathrm{TiO}_{2}$ nanoparticles (1A-C) typical transmission electron microscope images represent size distribution at magnification powers $\times 100,000$; (2D-F) zeta potential characterization of $n T i O 2$ in their applied doses (A) $5 \mathrm{mg} \cdot \mathrm{L}^{-1}$ (B) $10 \mathrm{mg} \cdot \mathrm{L}^{-1}$, and (C) $20 \mathrm{mg} . \mathrm{L}^{-1}$. 


\section{Phenotypic parameters of seedling growth}

Soybean seedling growth parameters 35 days after planting untreated and treated soybean seeds following the three treatments $\left(\mathrm{nTiO}_{2}, \mathrm{~Pb}\right.$, and $\mathrm{Pb}$ adsorbate solutions) were estimated and used as parameters of seedling development (Table 1).

Table 1. Parameters of soybean seedling growth affected by $\mathrm{nTiO}_{2}, \mathrm{~Pb}$ and $\mathrm{Pb}$ adsorbate solutions 35 days after planting treated and untreated (control) germinated seeds.

\begin{tabular}{|c|c|c|c|c|c|c|c|c|c|c|c|}
\hline \multirow[b]{3}{*}{ Treatments } & \multirow[b]{3}{*}{$\begin{array}{l}\text { Dose } \\
\text { mg. } .^{-1}\end{array}$} & \multirow{2}{*}{\multicolumn{3}{|c|}{ Mean Lengths (cm) }} & \multicolumn{3}{|c|}{ Seedling growth parameters \pm SD } & \multirow{3}{*}{$\begin{array}{l}\text { Seedling } \\
\text { vigor } \\
\text { index } \\
\text { (VI) }\end{array}$} & \multirow[b]{3}{*}{$\begin{array}{l}\text { Tolerance } \\
\text { index (TI) }\end{array}$} & \multirow{2}{*}{\multicolumn{2}{|c|}{ Leaf parameters }} \\
\hline & & & & & Phyto & xicity $\%$ & & & & & \\
\hline & & Root & Shoot & Seedling & Root length & Shoot length & $\begin{array}{l}\text { root /shoot } \\
\text { ratios }\end{array}$ & & & $\begin{array}{l}\text { No of Leaves } \\
\text { / plants }\end{array}$ & $\begin{array}{l}\text { Leaf surface } \\
\text { area/plant } \\
\left(\mathrm{cm}^{2}\right)\end{array}$ \\
\hline \multirow[t]{2}{*}{ Control } & 0.00 & $43.03 \pm 1.60$ & $25.67 \pm 1.16$ & $69.00 \pm 1.09$ & 00.00 & 00.00 & $1.69 \pm 0.05^{3}$ & 7210.56 & 100 & $13.33 \pm 1.16^{2}$ & $14.40 \pm 0.10^{7}$ \\
\hline & 5.00 & $43.68 \pm 2.08^{*}$ & $24.67 \pm 2.31^{*}$ & $68.35 \pm 2.20^{*}$ & $5.71 \pm 1.53$ & $10.84 \pm 0.65$ & $1.77 \pm 0.20^{\circ}$ & 6883.57 & 95.59 & $12.00 \pm 1.00^{*}$ & $13.00 \pm 1.00^{*}$ \\
\hline \multirow{4}{*}{$\mathrm{nTiO}_{2}$} & 10.00 & $47.67 \pm 3.06$ & $27.67 \pm 0.57^{*}$ & $75.34 \pm 2.11$ & 00.00 & $-00.14 \pm 0.15$ & $1.67 \pm 0.06^{*}$ & 8243.69 & 108.73 & $16.67 \pm 1.53$ & $14.63 \pm 0.15$ \\
\hline & 20.00 & $41.00 \pm 1.00^{*}$ & $22.00 \pm 2.65^{*}$ & $63.00 \pm 1.83^{*}$ & $11.50 \pm 1.08$ & $17.51 \pm 1.21$ & $1.86 \pm 0.23$ & 5249.49 & 89.85 & $11.0 \pm 1.00^{*}$ & $12.90 \pm 0.03$ \\
\hline & 75.00 & $35.33 \pm 1.53^{*}$ & $19.33 \pm 1.35^{*}$ & $54.66 \pm 1.44^{*}$ & $23.74 \pm 1.40$ & $30.14 \pm 1.77$ & $1.83 \pm 0.07^{*}$ & 3794.50 & 75.70 & $10.33 \pm 0.58^{*}$ & $11.70 \pm 0.10^{*}$ \\
\hline & 100.00 & $33.67 \pm 1.53^{*}$ & $17.67 \pm 1.53^{*}$ & $51.34 \pm 1.50^{*}$ & $27.32 \pm 1.10$ & $36.10 \pm 0.52$ & $1.91 \pm 0.11$ & 3279.60 & 72.14 & $9.68 \pm 0.58^{\circ}$ & $9.23 \pm 0.06 *$ \\
\hline $\mathrm{Pb}$ & 150.00 & $30.67 \pm 3.06^{*}$ & $15.83 \pm 0.76^{*}$ & $46.50 \pm 1.87^{*}$ & $44.28 \pm 0.88$ & $54.79 \pm 1.47$ & $1.94 \pm 0.15$ & 2065.07 & 65.71 & $8.00 \pm 1.00^{*}$ & $5.70 \pm 0.05^{*}$ \\
\hline \multirow{3}{*}{$\begin{array}{l}\mathrm{Pb} \text { adsorbate } \\
\text { solutions }\end{array}$} & 75.00 & $42.00 \pm 1.00^{*}$ & $25.50 \pm 2.52^{*}$ & $67.50 \pm 1.67^{*}$ & $9.35 \pm 1.15$ & $10.84 \pm 1.67$ & $1.70 \pm 0.21$ & 6888.96 & 97.99 & $12.00 \pm 0.03$ & $13.90 \pm 0.30^{*}$ \\
\hline & 100.00 & $41.67 \pm 2.08^{*}$ & $22.33 \pm 1.53^{*}$ & $64.00 \pm 1.08^{*}$ & $12.23 \pm 1.23$ & $19.29 \pm 2.35$ & $1.82 \pm 0.17$ & 6040.00 & 94.14 & $11.33 \pm 0.58^{*}$ & $13.63 \pm 0.55^{*}$ \\
\hline & 150.00 & $39.00 \pm 2.65^{*}$ & $19.67 \pm 1.16^{*}$ & $58.67 \pm 1.91^{*}$ & $15.43 \pm 1.19$ & $28.91 \pm 1.34$ & $1.98 \pm 0.24$ & 5400.25 & 88.57 & $9.68 \pm 0.58^{*}$ & $10.70 \pm 0.10^{*}$ \\
\hline
\end{tabular}

*The mean difference is significant at the 0.05 level.

Seedling vigor (VI) I and tolerance index (TI) varied between the applied treatments, with each treatment having a specific effect. $\mathrm{nTiO}_{2} 10 \mathrm{mg} \cdot \mathrm{L}^{-1}$ dose showed a significant increase in (VI) I and highest TI, reaching a value of 8243.69 and $108.73 \%$ respectively when compared to that of untreated control which reached the value of 7210.56 for (VI) I and $100.00 \%$ for TI. However, (VI) I and TI decreased significantly in seeds treated with the highest $\mathrm{Pb}$ dose $\left(150 \mathrm{mg} . \mathrm{L}^{-1}\right)$, which reached the values of 2065.07 and $65.71 \%$ respectively. After the adsorption process, the negative effects on (VI) I and TI were ameliorated and instead increased in the treatments of the three $\mathrm{Pb}$ adsorbate solutions over their values before adsorption. The maximum values of (VI) I and TI were 6888.96 and $97.99 \%$ respectively of $75 \mathrm{mg} . \mathrm{L}^{-1} \mathrm{~Pb}$ adsorbate solution compared to their values of the same $\mathrm{Pb}$ dose before adsorption compared to their values of the same $\mathrm{Pb}$ dose before adsorption (3794.5 and 75.70, respectively) (Table 1).

The $10 \mathrm{mg} . \mathrm{L}^{-1} \mathrm{nTiO}$ dose exhibited stimulatory effects, increasing the value of all leaf parameters based on mean number of leaves/plant and leaf surface area when compared to that of the untreated leaves and contrary to the other two $\mathrm{nTiO}_{2}$ doses. However, the different $\mathrm{Pb}$ doses had significant adverse effects on leaf parameters based on dose dependency compared to that of the $\mathrm{nTiO}_{2}$ doses. The three $\mathrm{Pb}$ adsorbate solutions showed good amelioration in all leaf parameters when compared to that of the equivalent doses of $\mathrm{Pb}$ before adsorption.

The percentage phytotoxicity of root and shoot lengths varied among the different treatments. The percentage phytotoxicity at optimal $10 \mathrm{mg} . \mathrm{L}^{-1} \mathrm{nTiO}_{2}$ dose reached $0.00 \%$ and $-0.14 \pm 0.15 \%$, for roots and shoots, respectively, while the lower and higher doses of $\mathrm{nTiO}_{2}\left(5 \mathrm{mg} . \mathrm{L}^{-1}\right.$ and $20 \mathrm{mg} . \mathrm{L}^{-1}$, respectively) showed gradually increasing phototoxicity percentages compared to that of the untreated control (which showed no evidence of toxicity) (Table 1). 
Meanwhile, the percentage phytotoxicity of shoot and root lengths significantly increased with the increasing $\mathrm{Pb}$ dose, with the maximum phytotoxicity values reaching $44.28 \pm 0.88 \%$ and $54.79 \pm 1.47 \%$, respectively, for the higher $\mathrm{Pb}$ dose $\left(150 \mathrm{mg} . \mathrm{L}^{-1}\right)$ compared with that of the untreated seedlings and that of the highest $\mathrm{nTiO}_{2}$ dose. Most interestingly, the three doses of $\mathrm{Pb}$ adsorbate solution showed a significant reduction in phototoxicity percentage of root and shoot lengths reached the values of $9.35 \pm 1.15 \%$ and $10.84 \pm 1.67 \%$, respectively, recorded at the $75 \mathrm{mg} . \mathrm{L}^{-1} \mathrm{~Pb}$ adsorbate solution treatment, which were $23.74 \pm 1.40 \%$ and $30.14 \pm 1.77 \%$, respectively (Table 1 ).

The data obtained from seedling growth parameters indicate that three $\mathrm{Pb}$ adsorbate solutions increased the seedling growth parameters (mean seedling lengths, (VI) I, (TI) and leaf parameters) and significantly decreased phytotoxicity of $\mathrm{Pb}$ compared to equivalent $\mathrm{Pb}$ doses used before adsorption process (Table 1). The best amelioration and attenuation of $\mathrm{Pb}$ was at adsorbate solutions of $75 \mathrm{mg} . \mathrm{L}^{-1} \mathrm{~Pb}$ dose compared to equivalent of this dose before adsorption.

Table 2 and Figure 2 show the effect of three doses of $\mathrm{nTiO}_{2}$; lead $(\mathrm{Pb}), \mathrm{Pb}$ adsorbate solutions on soybean pollen grains (PGs) performance. The data obtained illustrated that values of absolute pollen grain viability (APV) were significantly increased at the optimal nTiO2 dose, much higher than control PGs $\left(10 \mathrm{mg} . \mathrm{L}^{-1} \mathrm{nTiO}_{2}, 55.48 \pm 1.21 \%\right.$; control, $43.14 \pm 1.50 \%)$.

Table 2. Pollen grains (PGs) performance generated from untreated and treated soybean seeds with $\mathrm{nTiO}_{2}$, $\mathrm{Pb}$ and $\mathrm{Pb}$ adsorbate solutions.

\begin{tabular}{|c|c|c|c|c|c|c|c|}
\hline \multicolumn{8}{|c|}{ Pollen grains performance \pm SD } \\
\hline Treatments & $\begin{array}{l}\text { Dose } \\
\text { mg.L } \text { L }^{-1}\end{array}$ & $\begin{array}{l}\text { Total No. } \\
\text { PGs }\end{array}$ & $\begin{array}{l}\text { \% Morphological } \\
\text { homogeneity } \\
\text { (MH) }\end{array}$ & $\%$ Sterility & $\begin{array}{l}\text { \% non-viable } \\
\text { PGs }\end{array}$ & $\begin{array}{r}\% \text { germinated } \\
\text { pollen tube }\end{array}$ & $\begin{array}{l}\text { Absolute pollen } \\
\text { viability (APV) }\end{array}$ \\
\hline \multirow{2}{*}{ Control } & 0.00 & 1000 & $95.40 \pm 0.02$ & $2.80 \pm 0.12$ & $1.70 \pm 0.25$ & $45.93 \pm 0.20$ & $43.14 \pm 1.50$ \\
\hline & 5.00 & 1000 & $92.50 \pm 0.22$ & $12.75 \pm 0.30$ & $1.60 \pm 0.45$ & $27.23 \pm 1.34$ & $23.76 \pm 2.4$ \\
\hline \multirow{3}{*}{$\mathrm{nTiO}_{2}$} & 10.00 & 1000 & $97.50 \pm 0.10^{*}$ & $0.10 \pm 0.03^{*}$ & $0.00 \pm 0.50^{*}$ & $50.99 \pm 0.80$ & $55.48 \pm 1.21^{*}$ \\
\hline & 20.00 & 1000 & $87.20 \pm 0.15$ & $21.41 \pm 0.21$ & $2.10 \pm 0.10$ & $16.28 \pm 0.98$ & $13.20 \pm 0.98$ \\
\hline & 75.00 & 1000 & $77.20 \pm 0.08$ & $50.48 \pm 0.01$ & $4.80 \pm 1.30$ & $8.34 \pm 0.25$ & $4.80 \pm 0.57$ \\
\hline \multirow[t]{3}{*}{$\mathrm{Pb}$} & 100.00 & 1000 & $41.70 \pm 0.30^{*}$ & $69.74 \pm 0.11$ & $5.60 \pm 0.33$ & $5.25 \pm 0.55$ & $2.52 \pm 1.72$ \\
\hline & 150.00 & 1000 & $22.60 \pm 0.11^{*}$ & $83.07 \pm 1.21^{*}$ & $6.50 \pm 052^{*}$ & 2. $25 \pm 0.55$ & $0.89 \pm 2.10^{*}$ \\
\hline & 75.00 & 1000 & $96.20 \pm 0.10^{*}$ & $7.32 \pm 0.08$ & $1.15 \pm 0.40$ & $38.08 \pm 0.11$ & $39.67 \pm 1.45^{*}$ \\
\hline \multirow{2}{*}{$\begin{array}{l}\mathrm{Pb} \text { adsorbate } \\
\text { solutions }\end{array}$} & 100.00 & 1000 & 82. $90 \pm 0.14$ & $18.32 \pm 0.08$ & $2.40 \pm 0.25$ & $24.08 \pm 0.11$ & $19.67 \pm 1.45$ \\
\hline & 150.00 & 1000 & $54.10 \pm 1.20$ & $32.62 \pm 0.12$ & $3.70 \pm 1.30$ & $18.37 \pm 1.25$ & $12.38 \pm 0.98$ \\
\hline
\end{tabular}

*The mean difference is significant at the 0.05 level.

The obtained results also showed that morphological homogeneity (MH\%) of germinated pollen tube and germination index (GI) had the same trend of the above APV parameter which improved after exposure to $10 \mathrm{mg} \cdot \mathrm{L}^{-1} \mathrm{nTiO}_{2}$ dose but were reduced by the other $\mathrm{nTiO}_{2}$ doses $\left(5\right.$ and $\left.20 \mathrm{mg} . \mathrm{L}^{-1}\right)$; however, their effects were less than those of the $\mathrm{Pb}$ doses which were more toxic on these PGs parameters in a dose-dependent manner, as shown in (Table 2).

However, the sterility of pollen grains (PGs) was found to be dose-dependent as its increased as $\mathrm{Pb}$ doses increased, compared to that of untreated plants. The maximum value of PGs sterility was $83.07 \pm 1.21 \%$ from the $150 \mathrm{mg} . \mathrm{L}^{-1} \mathrm{~Pb}$ dose, whereas the minimum value was $1.10 \pm 0.03 \%$ from the $10 \mathrm{mg} \cdot \mathrm{L}^{-1} \mathrm{nTiO}_{2}$ dose, which was less than the sterility value of untreated samples $(2.80 \pm 0.12 \%)$. This indicates that the $10 \mathrm{mg} \cdot \mathrm{L}^{-1} \mathrm{nTiO}_{2}$ dose 
was more effective in reducing the PGs sterility and increasing the fertility and viability of soybean PGs.

Meanwhile, the three $\mathrm{Pb}$ adsorbate solutions resulted in a significant reduction of PGs sterility, ameliorating the PGs viability, and increasing their fertility compared to that of the equivalent $\mathrm{Pb}$ doses before adsorption process (Table 2 and Figure 2).

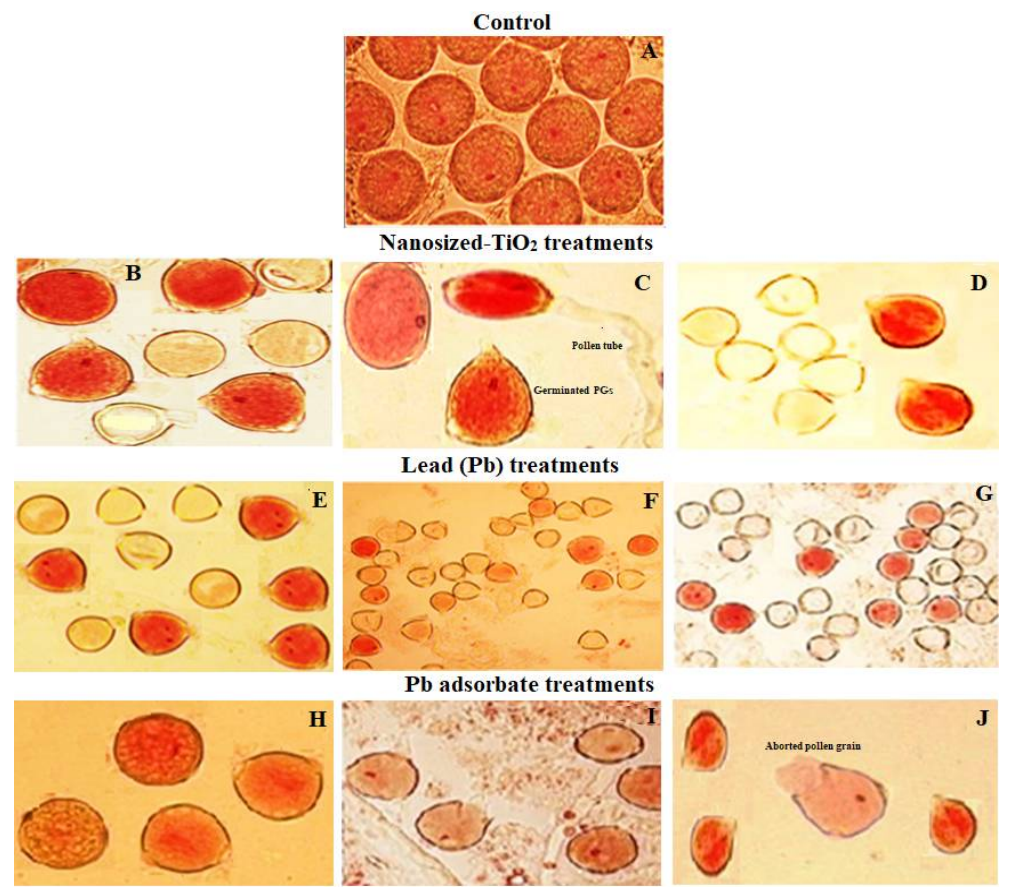

Figure 2. The most pronounced $\mathrm{PGs}$ parameters of soybean treated with $\mathrm{nTiO}_{2}, \mathrm{~Pb}$, and $\mathrm{Pb}$ adsorbate solutions alongside control PGs. A) Fertile stained pollen grains of the control group; B) Fertile colored PGs and colorless empty sterile PGs at $5 \mathrm{mg} . \mathrm{L}^{-1} \mathrm{nTiO} 2$ dose; C) Full germinated pollen tube and fertile colored germinated PGs at $10 \mathrm{mg} . \mathrm{L}^{-1} \mathrm{nTiO}_{2}$ dose; D) Fertile stained PGs and sterile empty PGs at $20 \mathrm{mg} \cdot \mathrm{L}^{-1} \mathrm{nTiO}_{2}$ dose; E) Small fertile stained PGs and sterile empty PGs at $75 \mathrm{mg} . \mathrm{L}^{-1} \mathrm{~Pb}$ dose; F) Few small germinated pollen tube with numerous sterile empty PGs at $100 \mathrm{mg} . \mathrm{L}^{-1} \mathrm{~Pb}$ dose; G) Few very small germinated pollen tube with numerous sterile empty PGs at $150 \mathrm{mg} \cdot \mathrm{L}^{-1} \mathrm{~Pb}$ dose, and; H-J) Variable range of fertile colored PGs treated with $\mathrm{Pb}$ adsorbate solutions based on the equivalent $\mathrm{Pb}$ dose prior to the adsorption process. Note: red PGs refer to fertile PGs while empty and colorless refer to sterile PGs.

\section{Estimation of variations in nuclear DNA content and genome size by flow cytometry}

A detailed description of the action of $\mathrm{nTiO}_{2}, \mathrm{~Pb}$, and $\mathrm{Pb}$ adsorbate solutions were focused on nuclei isolated from soybean seeds to estimate the alteration of nDNA content and genome size of treated nuclei alongside untreated samples by flow cytometry (FCM) as well as genome size per the chromosome number of soybean (Table 3 and Figure 3). The obtained results showed an increase in nuclear DNA content of soybean after being treated with two $\mathrm{nTiO}_{2}$ doses $\left(5\right.$ and $\left.10 \mathrm{mg} . \mathrm{L}^{-1}\right)$ which reached the value of $9.00 \pm 0.012$ and $9.62 \pm$ $0.002 \mathrm{pg}$, respectively, when compared to that of the nuclei isolated from untreated soybean seeds $(8.48 \pm 0.006 \mathrm{pg})$. Meanwhile, the nuclear DNA content of the $20 \mathrm{mg} \cdot \mathrm{L}^{-1} \mathrm{nTiO}_{2}$ dose decreased relative to the control group and reached $8.14 \pm 0.005 \mathrm{pg}$. 
Table 3. Nuclear DNA content and genome size of nuclei isolated from untreated and treated soybean seeds with nanosized- $\mathrm{TiO}_{2}, \mathrm{~Pb}$ and $\mathrm{Pb}$ adsorbate solutions.

\begin{tabular}{lcllll}
\hline Treatments & $\begin{array}{l}\text { Dose } \\
\text { mg.. }\end{array}$ & $\begin{array}{l}\text { Mean 2C nDNA } \\
\text { content }(\mathbf{p g})\end{array}$ & $\begin{array}{l}\text { 1C genome } \\
\text { size (Mbp) }\end{array}$ & Chromosome number & $\begin{array}{l}\text { Genome size/ } \\
\text { Chromosome number }\end{array}$ \\
\hline Control & 0.00 & $8.48 \pm 0.006$ & 8183.20 & & 204.58 \\
& 5.00 & $9.00 \pm 0.012$ & 8685.00 & & 217.13 \\
$\mathrm{nTiO} 2$ & 10.00 & $9.62 \pm 0.002$ & 9283.30 & & 232.09 \\
& 20.00 & $8.14 \pm 0.005$ & 7855.10 & $2 \mathrm{n}=40$ & 196.38 \\
& 75.00 & $8.02 \pm 0.023$ & 7739.30 & 180.49 \\
$\mathrm{~Pb}$ & 100.00 & $7.48 \pm 0.008$ & 7218.20 & & 174.67 \\
& 150.00 & $7.24 \pm 0.040$ & 6986.60 & & 222.68 \\
$\mathrm{~Pb}$ adsorbate & 75.00 & $9.23 \pm 0.004$ & 8906.95 & & 220.75 \\
solutions & 100.00 & $9.15 \pm 0.003$ & 8829.75 & & 212.54 \\
& 150.00 & $8.81 \pm 0.001$ & 8501.65 & & \\
\hline
\end{tabular}
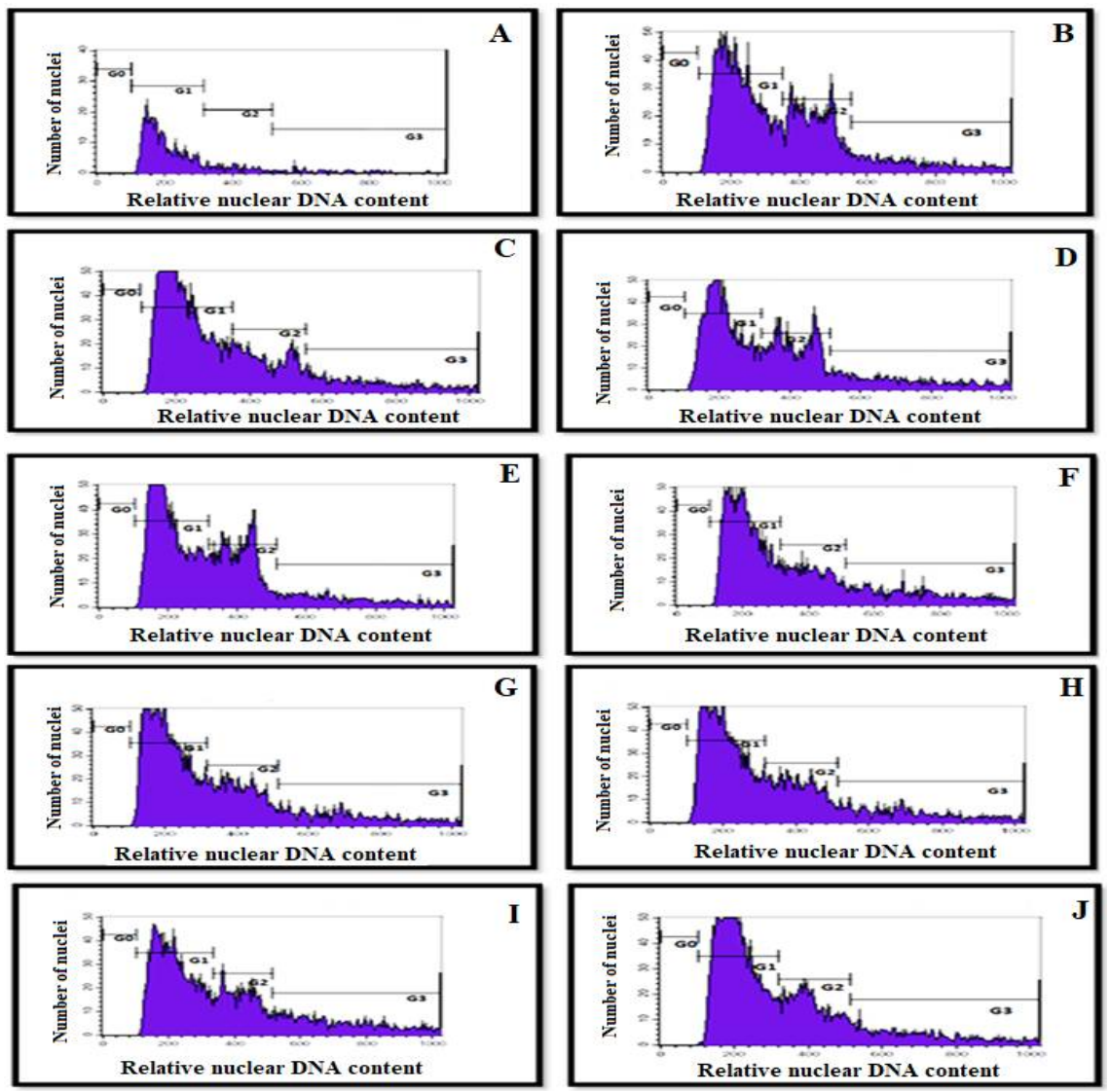

Figure 3. Flow cytometric analyses of nuclei isolated from untreated and treated soybean seeds which chopped and then stained with propidium iodide (A-J). $2 \mathrm{C}$ nDNA content (pg) estimated at $\operatorname{Gap}_{1}\left(\mathrm{G}_{1}\right)$ of interphase using peak position of the internal standard Human leucocytes (HLN) (2C nuclear DNA content $7.0 \mathrm{pg}$ ) as internal standard. (A) control, (B-D) $\mathrm{nTiO}_{2}$ doses, (E-G) $\mathrm{Pb}$ doses , and (H-J) $\mathrm{Pb}$ adsorbate solutions, respectively. 
In contrary, the nuclei of the $\mathrm{Pb}$-treated seeds showed the maximum decrease in nuclear DNA content at the $150 \mathrm{mg} \cdot \mathrm{L}^{-1} \mathrm{~Pb}$ dose of $7.24 \pm 0.040 \mathrm{pg}$ compared to that of the untreated nuclei, which reached $8.48 \pm 0.006 \mathrm{pg}$. Furthermore, soybean nuclei treated with one of the three $\mathrm{Pb}$ adsorbate solutions showed amelioration and improvement in nDNA content values. The nDNA content of the 75 and $100 \mathrm{mg} \cdot \mathrm{L}^{-1} \mathrm{~Pb}$ adsorbate solution reached the values of $9.23 \pm 0.006 \mathrm{pg}$ and $9.15 \pm 0.003 \mathrm{pg}$, respectively, well over the value of that of the untreated nuclei of $8.98 \pm 0.0067 \mathrm{pg}$ and in comparison to the values of nDNA content at the equivalent $\mathrm{Pb}$ doses used before adsorption $(8.02 \pm 0.023 \mathrm{pg}$ and $7.48 \pm 0.008$ pg, respectively) (Table 3 ).

Based on the conversion of $1 \mathrm{pg}=965 \mathrm{Mbp}$, the genome sizes of treated soybean nuclei were estimated. Genome size ranged from maximum value of $9283.30 \mathrm{Mbp}$ for the $10 \mathrm{mg} . \mathrm{L}^{-1} \mathrm{nTiO}_{2}$ dose to a minimum value of $6986.60 \mathrm{Mbp}$ at $150 \mathrm{mg} . \mathrm{L}^{-1} \mathrm{~Pb}$ dose, relative to that of the nuclei from untreated seedlings of $8183.2 \mathrm{Mbp}$.

On the other hand, the $\mathrm{Pb}$ adsorbate from aqueous solution of 75 and $100 \mathrm{mg} \cdot \mathrm{L}^{-1} \mathrm{~Pb}$ doses showed an increase in genome size to $8906.95 \mathrm{Mpb}$ and $8829.75 \mathrm{Mpb}$, respectively, to be larger than that of the untreated soybean of $8665.7 \mathrm{Mpb}$ and of the equivalent $\mathrm{Pb}$ doses (7739.30 Mpb and 7218.20 Mpb, respectively) (Table 3 and Figure 3).

\section{Single cell gel electrophoresis (SCGE) or comet assay for detection of DNA damage}

Table 4 and Figure 4(A-J) show remarkable variation in the extent of DNA damage in soybean nuclei exposed to three treatments of $\mathrm{nTiO}_{2}, \mathrm{~Pb}$, and $\mathrm{Pb}$ adsorbate solutions alongside the untreated one. This variation reflects the specific action of these treatments on nDNA.

Table 4. Extent of nuclear DNA damage identified by single-cell gel electrophoresis (SCGE) of nuclei isolated from untreated and treated soybean seeds with nanosized- $\mathrm{TiO} 2, \mathrm{~Pb}$ and $\mathrm{Pb}$ adsorbate solutions.

\begin{tabular}{|c|c|c|c|c|c|c|}
\hline Treatments & $\begin{array}{l}\text { Dose } \\
\text { mg. } .^{-1}\end{array}$ & $\begin{array}{l}\text { Tail } \\
\text { (damaged DNA) } \\
\% \\
\end{array}$ & $\begin{array}{l}\text { Head } \\
\text { (undamaged DNA) } \\
\% \\
\end{array}$ & $\begin{array}{l}\text { Tail length } \\
(\mu \mathrm{m})\end{array}$ & $\begin{array}{l}\text { Tailed DNA } \\
\%\end{array}$ & $\begin{array}{l}\text { Tail Moment } \\
\text { Unit }\end{array}$ \\
\hline \multirow[t]{2}{*}{ Control } & 0.00 & 4 & 96 & 1.88 & 1.54 & 3.61 \\
\hline & 5.00 & 9 & 91 & 2.66 & 2.51 & 6.68 \\
\hline \multirow{3}{*}{$\mathrm{nTiO}_{2}$} & 10.00 & 2 & 98 & 1.06 & 1.30 & 3.54 \\
\hline & 20.00 & 11 & 89 & 3.11 & 3.16 & 10.83 \\
\hline & 75.00 & 15 & 85 & 5.73 & 5.57 & 31.92 \\
\hline \multirow[t]{3}{*}{$\mathrm{Pb}$} & 100.00 & 17 & 83 & 6.21 & 6.43 & 39.93 \\
\hline & 150.00 & 20 & 80 & 6.89 & 6.41 & 44.17 \\
\hline & 75.00 & 5 & 95 & 2.11 & 2.30 & 4.81 \\
\hline \multirow{2}{*}{$\begin{array}{l}\mathrm{Pb} \text { adsorbate } \\
\text { solutions }\end{array}$} & 100.00 & 7 & 93 & 2.68 & 2.49 & 6.67 \\
\hline & 150.00 & 8 & 92 & 2.88 & 2.71 & 7.80 \\
\hline
\end{tabular}

The $10 \mathrm{mg} \cdot \mathrm{L}^{-1} \mathrm{nTiO}$ dose showed minimum DNA migration (Tailed $2 \%$ ) with tail length of $1.06 \mu \mathrm{m}$, tailed DNA \% of 1.30, and tail moment unit of 3.54 (Figure 4C), less than the DNA migration exhibited by the nuclei of untreated soybean which reached (Tailed $4 \%$ ) with tail length of $1.88 \mu \mathrm{m}$, tailed DNA \% of 1.54 , and tail moment unit of 3.61 (Figure 4A). This indicates that this $\mathrm{nTiO}_{2}$ dose could reduce nDNA damage and protect 
DNA while the other $\mathrm{nTiO}_{2}$ doses induced nDNA damage in a dose-dependent pattern (Table 4 and Figure 4B and D).
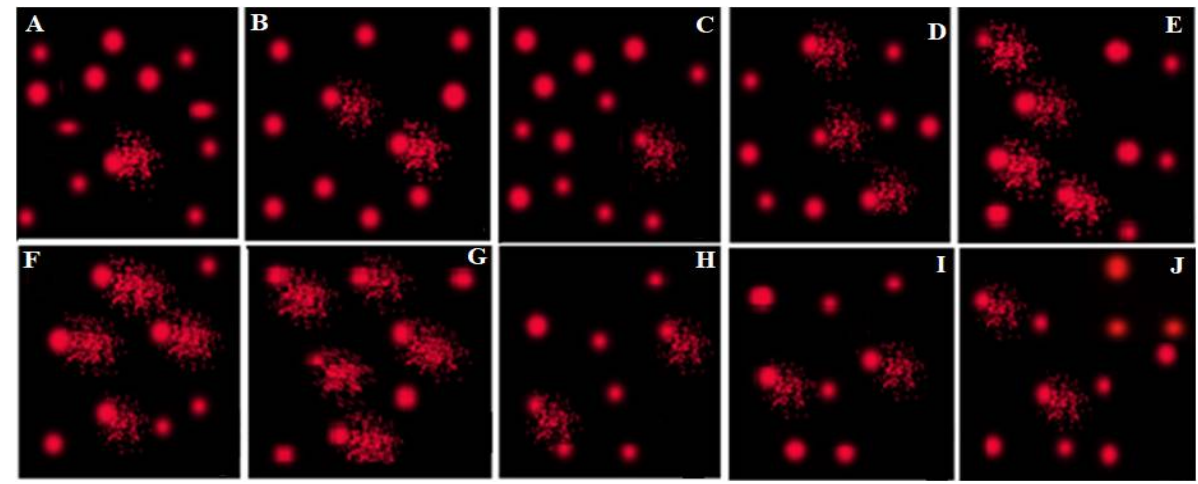

Figure 4. Comet images prepared by single cell gel electrophoresis (SCGE) show the variable extent of nuclear DNA damage in the nuclei isolated from treated and untreated soybean seeds. The images A-J represent control (A) $\mathrm{nTiO}_{2}$ doses $(\mathrm{B}-\mathrm{D}), \mathrm{Pb}$ doses $(\mathrm{E}-\mathrm{G})$, and $\mathrm{Pb}$ adsorbate solutions (H-J), respectively.

On the contrary, the $150 \mathrm{mg} . \mathrm{L}^{-1} \mathrm{~Pb}$ dose scored the maximum DNA migration (Tailed 20\%) with tail length of $6.89 \mu \mathrm{m}$, tailed DNA \% of 6.41 and tail moment unit of 44.17, indicating that the $\mathrm{Pb}$ treatment increase nDNA damage and was very toxic to the nDNA of soybean cells (Figure 4E-G) .

Furthermore, the data obtained in the present study demonstrated evidence of the reduction in nDNA damage by $\mathrm{Pb}$ adsorbate solutions based on equivalent $\mathrm{Pb}$ dosedependent effect seen before adsorption. The clear amelioration of nDNA content was observed from the adsorbate $75 \mathrm{mg} . \mathrm{L}^{-1}$ solution of $\mathrm{Pb}$ which scored DNA migration (Tailed $5 \%$ ) with tail length of $2.11 \mu \mathrm{m}$, tailed DNA \% of $2.30 \%$, and tail moment unit of 4.81 (Figure 4H-J) compared to the equivalent $\mathrm{Pb}$ dose without adsorption which scored DNA migration (Tailed $15 \%$ ) with tail length, $5.73 \mu \mathrm{m}$; tailed DNA \%, 5.57, and; tail moment unit, 31.92).

\section{RAPD-PCR bioassay for detection of alterations and DNA damage}

RAPD-PCR analysis was employed in the current study to evaluate the extent of the DNA alterations in soybean treated with the different doses of $\mathrm{nTiO}_{2}, \mathrm{~Pb}$, and $\mathrm{Pb}$ adsorbate solutions alongside untreated samples. Each treatment in addition to each primer used exhibited distinctive quantitative and qualitative alterations in electrophoretic banding pattern of treated DNA compared with each other and with the untreated controls.

Twenty random primers were used for the RAPD analysis, in which only four primers (P-12, P-14, P-15, and P-19) succeeded to produce clear reproducible DNA bands and gave satisfactory results with many alterations in the RAPD profiles. The alterations in DNA banding pattern based on changes in number of amplified DNA bands, band sizes (bp), bands intensities, appearance of new bands (unique bands) and disappearance of some bands (polymorphic bands) are shown in (Table 5) and (Figure 5).

In total, three hundred and fifty-six (356) reproducible DNA bands were scored after using the four primers (with an average of 89.00 bands/primer), resulting in a 
reproducible set of DNA bands with variable sizes that were specific for each primer on gel electrophoresis. Of these, 189 polymorphic bands were obtained with value of 53.09\%, out of which 143 bands were unique (40.17\%) and 46 bands non-unique $(12.92 \%)$ while monomorphic bands were absent. The total values of polymorphism generated by four primers were $100 \%$ because of the absence the monomorphic bands for these primers. On the other hand, the highest number of gene products (115 bands; $32.31 \%$ ) were generated by primer-12 while the lower number of 70 bands (19.66\%) were generated by primer-15 (Table 5).

Table 5. RAPD-PCR amplification products of DNA isolated from soybean seeds treated with $\mathrm{nTiO} 2, \mathrm{~Pb}$, and $\mathrm{Pb}$ adsorbate solutions using four random primers. Lane 1, control; lanes 2-4, nanosized $\mathrm{TiO}_{2}$ doses (5, 10 , and $20 \mathrm{mg} . \mathrm{L}^{-1}$, respectively); 5-7 Pb doses (75, 100, and $150 \mathrm{mg} . \mathrm{L}^{-1}$, respectively), and; (8-10) three $\mathrm{Pb}$ adsorbate solutions.

\begin{tabular}{|c|c|c|c|c|c|c|c|c|c|c|c|c|c|c|c|c|c|c|c|c|c|}
\hline \multirow[b]{3}{*}{ Primer code } & \multirow[b]{3}{*}{$\begin{array}{l}\text { Primers } \\
\text { sequences }\left(5^{\prime} \rightarrow\right. \\
\left.3^{\prime}\right)\end{array}$} & \multirow[b]{3}{*}{$\begin{array}{l}\text { Amplicon } \\
\text { Lengths } \\
\text { (bp) }\end{array}$} & \multirow[b]{3}{*}{$\begin{array}{l}\text { Lane } \\
1\end{array}$} & \multirow[b]{3}{*}{$\begin{array}{l}\text { Lane } \\
2\end{array}$} & \multirow{2}{*}{\multicolumn{6}{|c|}{ Total number of scorable bands in each Lane }} & \multirow[b]{3}{*}{$\begin{array}{l}\text { Lane } \\
9\end{array}$} & \multirow[b]{3}{*}{$\begin{array}{l}\text { Lane } \\
10\end{array}$} & \multirow{2}{*}{\multicolumn{2}{|c|}{ Total bands }} & \multirow{2}{*}{\multicolumn{2}{|c|}{ Unique }} & \multicolumn{5}{|c|}{ Polymorphic bands } \\
\hline & & & & & & & & & & & & & & & & & \multicolumn{2}{|c|}{$\begin{array}{l}\text { Non - } \\
\text { Unique }\end{array}$} & \multicolumn{2}{|c|}{ Polymorphic } & \multirow[t]{2}{*}{ Polymorphism\% } \\
\hline & & & & & $\begin{array}{l}\text { Lane } \\
3\end{array}$ & $\begin{array}{l}\text { Lane } \\
\mathbf{4}\end{array}$ & $\begin{array}{l}\text { Lane } \\
\mathbf{5} \\
\end{array}$ & $\begin{array}{l}\text { Lane } \\
\mathbf{6} \\
\end{array}$ & $\begin{array}{l}\text { Lane } \\
7\end{array}$ & $\begin{array}{l}\text { Lane } \\
\mathbf{8} \\
\end{array}$ & & & No & $\%$ & No & $\%$ & No & $\%$ & No & $\%$ & \\
\hline 12 & CAC CGT ATC C & $950-200$ & 14 & 12 & 14 & 13 & 11 & 9 & 7 & 13 & 11 & 11 & 115 & 32.31 & 51 & 44.35 & 13 & 11.30 & 64 & 55.65 & 100 \\
\hline 14 & CTT CCC CAA G & $983-274$ & 12 & 10 & 8 & 9 & 8 & 7 & 8 & 9 & 10 & 7 & 88 & 24.72 & 26 & 29.55 & 9 & 10.23 & 35 & 39.77 & 100 \\
\hline 15 & CAT CCG TGC T & $885-075$ & 7 & 5 & 13 & 5 & 7 & 6 & 5 & 8 & 6 & 8 & 70 & 19.66 & 37 & 52.86 & 8 & 11.43 & 45 & 64.29 & 100 \\
\hline 19 & CTG GGG ACT T & $900-100$ & 8 & 10 & 11 & 9 & 7 & 9 & 6 & 8 & 8 & 7 & 83 & 23.31 & 29 & 34.94 & 16 & 19.28 & 45 & 54.23 & 100 \\
\hline \multirow{2}{*}{$\begin{array}{l}\text { Overall total } \\
\% \text { of total bands } \\
\text { in each Lane }\end{array}$} & & & 41 & 37 & 46 & 36 & 33 & 31 & 26 & 38 & 35 & 33 & 356 & 100 & 143 & 40.17 & 46 & 12.92 & 189 & 53.09 & 100 \\
\hline & & & 11.52 & 10.39 & 12.93 & 10.11 & 9.27 & 8.71 & 7.30 & 10.67 & 9.83 & 9.27 & & & & & & & & & \\
\hline
\end{tabular}
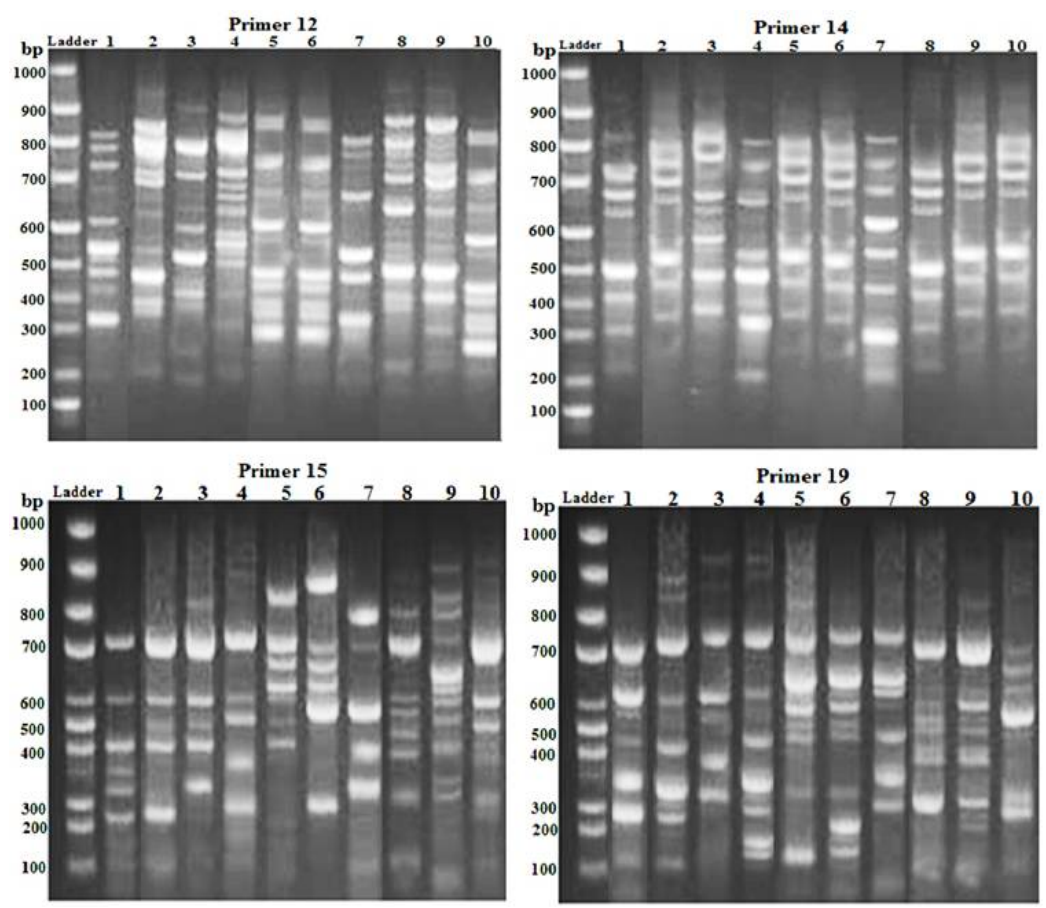

Figure 5. RAPD profiles of genomic DNA of soybean generated by four random decamer primers. The samples 1-10 represent control (1) nTiO2 doses (2-4), $\mathrm{Pb}$ doses (5-7), and $\mathrm{Pb}$ adsorbate solutions (8-10), respectively. 
Furthermore, the maximum number of gene products (46 bands; 12.93\%) was observed in the soybean treated with the $10 \mathrm{mg} . \mathrm{L}^{-1} \mathrm{nTiO} 2$ dose while the minimum number of bands $(26 ; 7.30 \%)$ was at the $150 \mathrm{mg} . \mathrm{L}^{-1} \mathrm{~Pb}$ dose compared to the number of gene products of the untreated samples which reached 41 bands (11.52\%), as shown in (Table 5).

The results of RAPD analysis were performed by considering the bands that appear in the control sample as the criterion of the judgment. A RAPD polymorphism included disappearance of a control band and appearance of a new one following treatment.

The three $\mathrm{Pb}$ adsorbate solutions showed an increase in the number of amplified DNA bands based on equivalent $\mathrm{Pb}$ dose-dependent effects. It reached $38 \mathrm{DNA}$ bands $(10.67 \%)$ at the adsorbate $75 \mathrm{mg} . \mathrm{L}^{-1}$ solution of $\mathrm{Pb}$ compared to the equivalent $\mathrm{Pb}$ dose without adsorption which scored 33 DNA bands (9.27\%) (Table 5 and Figure 5).

\section{DISCUSSION}

The results obtained in this study demonstrated that all parameters of soybean seedling growth were significantly stimulated and improved upon exposure to $10 \mathrm{mg} . \mathrm{L}^{-1}$ $\mathrm{nTiO}_{2}$ dose being higher than those of the untreated samples. Therefore, this dose was considered as optimal, while the two $\mathrm{nTiO}_{2}$ doses higher and lower than this dose induced a variable reduction in these growth parameters compared to that of the optimal dose. The significant effect of $\mathrm{nTiO}_{2}$ on soybean seedling growth parameters may be attributed to their small particle size and their degree of homogeneous dispersion, which may influence their speed of penetration into the seed coat.

The positive and promoting action of the optimal $\mathrm{nTiO}_{2}$ dose $\left(10 \mathrm{mg} \cdot \mathrm{L}^{-1}\right)$ on growth of soybean seeds may due to the creation pores in seed coats during its penetration and consequently, enhancing the absorbance and uptake of water into seeds and cells or may be due to increasing some important enzymes such as nitrate reductase in the soybean seeds or by stimulating transcription of plant genes responsible for the accumulation of water channel proteins (aquaporins) in soybean tissues (Marchiol et al., 2016). Additionally, interpretation the promoting action of this optimal dose may be due to promotion of the antioxidant system in soybean cells causing increased strength and resistance to oxidative stress by reducing ROS which may hasten seed germination and improve early seedling growth (Dolatabadi et al., 2016). In this respect also, Mittler (2017) reported that $\mathrm{nTiO}_{2}$ at certain doses can regulate and promote plant growth and enhance its tolerance by modulating ROS-dependent signalling pathway(s), which is dependent upon enhancing activities of enzymatic antioxidants and consequently, reducing oxidative damages of DNA.

On the other hand, the toxic action of $\mathrm{nTiO}_{2}$ at high dose $\left(20 \mathrm{mg} . \mathrm{L}^{-1}\right)$ on soybean seedling growth may be interpreted based on accumulation of $\mathrm{TiO}_{2}$ nanoparticles on external surfaces of soybean seeds causing clogging of the pores which may interrupt the uptake of water though the seed coat and leading to adverse and negative action, such as increasing cellular oxidative stress, accumulation of harmful reactive oxygen species (ROS), and reduction of the antioxidant defense system which lead to significant damage to membranes and cellular macromolecules (such as DNA and proteins) and consequently, disturbance of several metabolic cycles during early seedling growth (Dolatabadi et al., 2016). In this respect, the results match the study of Ruffini-Castiglione et al. (2011) which showed reduction and alteration in development growth of Zea mays L. and Vicia narbonensis $\mathrm{L}$. after treatment with higher $\mathrm{nTiO}_{2}$ concentrations. 
Meanwhile, the three $\mathrm{Pb}$ doses had adverse and toxic effects on soybean seeds by the reduction of seedling growth parameters, even in small doses. This may be due to the ability of $\mathrm{Pb}$ to produce oxidative stress by increasing ROS in the soybean cells that affects plant metabolic processes leading to inhibition of important enzymes required for cell division and seedling growth, as explained by Pourrut et al. (2011).

Pollen germination and growth of pollen tubes are, in principle, necessary for fertilization and seed formation in flowering plants, and good fruit set, and high crop yield depend on healthy pollen grains (Abdelhaliem et al., 2013). Pollen staining tests are among the most reliable and widely used pollen viability tests; however, in some cases pollen grain germination tests are necessary to observe the realized viability of pollen grains. In the current study, the cytogenetic investigations indicated that soybean pollen grain performance showed a significant stimulation and increase at the optimal $\mathrm{nTiO}_{2}$ dose $(10$ mg. $\mathrm{L}^{-1}$ ) in comparison to that of the untreated samples, while the other two $\mathrm{nTiO}_{2}$ doses showed gradual reduction depending on dose when compared to that of the untreated sample. This study interpreted induction and increasing of viability, fertility and germination of soybean pollen grains by the optimal $\mathrm{nTiO}_{2}$ dose may be due to the antioxidant defense system of pollen grains which protects their DNA from oxidative damage by ROS without too much damage. This indicates the potential use of this dose in crop yield improvement. On the contrary, the remained $\mathrm{nTiO}_{2}$ doses especially high dose induced genotoxic and oxidative action in soybean PGs. These actions may be due to the induction of oxidative damage in these PGs by production of the free radical oxygen that lead to higher frequency of chromosomal aberrations and DNA damage which in turn can affect the vigor, pollen grains fertility and likely to persist in seeds yield or even longer due to the accumulative genotoxicity, as explained by Abdelhaliem et al. (2013).

On the other hand, the three $\mathrm{Pb}$ doses showed a strong reduction in soybean PGs performance in dose dependent manner. The high $\mathrm{Pb}$ dose showed inhibition of pollen germination and pollen tube growth leading to the highest percentage of sterility of pollen grains. This may be due to the induction of high ROS in pollen mother cells which may cause induction of structural changes in the DNA, such as chromosomal rearrangement, strand breaks, base deletions, pyrimidine dimers, cross-links and base modifications, mutations, and other genotoxic effects, in accordance with (Pourrut et al., 2011). The reduction of pollen grain germination and inhibited viability may be due to decreased effectiveness of pollination and fertilization, consequently affecting the quantity and quality of seed set.

The current study showed remarkable variations in the extent of DNA damage experience by the nuclei of soybeans treated with $\mathrm{nTiO}_{2}$ and $\mathrm{Pb}$. The increase in nuclear DNA content and genome size as well as minimum DNA migration or DNA damage scored at the optimal $\mathrm{nTiO}_{2}$ dose as illustrated by flow cytometry and comet assay, respectively, may be due to increased antioxidant activity of soybean cells by this dose leading to the scavenging of free radicals, providing nDNA with adequate resistance and protection against oxidative damage.

On the contrary, the three $\mathrm{Pb}$ doses resulted in an obvious reduction in nuclear DNA content and genome size and induced an increase in migration and damage of soybean DNA when comparison to that of the untreated samples. This may be due to the ROS generated by these toxic treatments attacking DNA and producing lesions via base deletion, pyrimidine dimers, cross-links, DNA strand breaks, chain breaks, modification of 
carbohydrate parts and nitrogenous bases by oxidation (Nas and Ali, 2018). Therefore, $\mathrm{Pb}$ could induce different types of DNA damage in exposed nuclei which might be the cause for the arrest at the G2/M checkpoint. On the other hand, the Pb treatments, especially the highest dose may increase chromosomal sticky which led to chromosomal and DNA damage and consequently, a reduction in nuclear DNA content which resulted in unequal distribution of the DNA in the daughter cells. This DNA damage may influence the expression of several genes and, consequently, the synthesis of specific proteins that control many metabolic processes in soybean cells such as plant development, cell cycle, pollen grains fertility, fertilization, and seed formation.

The RAPD-PCR used in this study scored a wide range of DNA damage and specific-level qualitative and quantitative alterations in amplified DNA profiles. Different sizes of DNA bands may be interpreted as score separated loci based on the presence (amplification) and absence (non-amplification) of DNA segments by RAPDPCR. The highest number of amplified DNA bands (45) generated by four random RAPD primers scored at optimal $\mathrm{nTiO}_{2}$ dose compared to 41 DNA bands for untreated DNA. The increase in the number of amplified DNA bands (genes) at this dose may be attributed to gene expression of some genes for synthesis of proteins such as water channel proteins (aquaporins) that essential for cell division, plasma membrane formation, and promotion of water transport leading to activation the cellular metabolic processes (Lyu et al., 2017). The increase may also be explained on the basis that this optimal $\mathrm{nTiO}_{2}$ dose likely caused a large addition of nitrogenous bases or insertion of the amplified regions at the genomic level.

Alterations the characteristic DNA banding pattern generated by RAPD analysis observed at the highest dose of $\mathrm{nTiO}_{2}$ and three $\mathrm{Pb}$ doses may be explained based on the biological way by which each of these treatments interacts with DNA or by the production of ROS induced genotoxic DNA damage. This ROS may induce structural changes in the DNA, which may reflect the structure of the genomic DNA due to altering the distance between two annealing sites and deleting an existing site or as a reflection of the variation in gene expression (Dhakshanamoorthy et al., 2011). This study observed that the characteristic changes in the RAPD profiles ranged from the gain of DNA bands (unique DNA band), which may be due to addition or insertions and transposition of some genes induced by the treatments, to loss of DNA bands (polymorphic DNA band) and intensities of DNA bands which may be due to large deletions of amplified DNA regions or breaks in double-strand of the DNA molecule or a single base change in the genomic DNA which was induced by other treatments (Dhakshanamoorthy et al., 2011).

Data obtained in this study illustrated that the application of $\mathrm{Pb}$ adsorbate solutions on soybean seeds induced a significant increase and improvement of seedling growth parameter and alleviation of phytotoxic action of $\mathrm{Pb}$ on pollen grains and $\mathrm{DNA}$, resulting in amelioration and increasing the viability and fertility of PGs and protection of DNA from oxidative damage comparable to that of treated soybean seeds with three $\mathrm{Pb}$ doses used before adsorption process. Consequently, when $\mathrm{Pb}$ adsorbate solutions were applied to soybean seeds, this may have induced the capacity of antioxidant 
defense system in soybean cells, reducing free radicals and the subsequent genotoxic action of $\mathrm{Pb}$.

\section{CONCLUSIONS}

In conclusion, we demonstrated that the optimal dose $\left(10 \mathrm{mg} \cdot \mathrm{L}^{-1}\right)$ of $\mathrm{nTiO}_{2}$ induced positive and stimulatory actions on soybean cells as evaluated by bioassays used while other doses induced negative actions, especially at the highest doses. Thus, the study suggests that this optimal $\mathrm{nTiO}_{2}$ dose should be utilized to develop ecofriendly and effective 'nanofertilizers'.

The data obtained from phenotypic parameters, cytogenetic test of PGs, and DNA bioassays (flow cytometry, comet assay, and RAPD-PCR) indicated that powdered state (10 $\mathrm{mg}$ ) of optimal $\mathrm{nTiO}_{2}$ dose exhibited a good adsorbent affinity for adsorbing $\mathrm{Pb}$ onto its surface, leading to mitigation of $\mathrm{Pb}$ and consequently, increased vitality and tolerance resistance of soybean plant to $\mathrm{Pb}$ toxicity and improved the viability and fertility of PGs and protected DNA from damage when applied to soybean. This will open an avenue for using $\mathrm{nTiO}_{2}$ to protect crops from heavy metal toxicity.

To the best of our knowledge, this type of study has not been conducted until now. We recommend developing an efficient $\mathrm{nTiO}_{2}$ adsorbent for $\mathrm{Pb}$ or any heavy metal as a widely applicable means in agriculture for the protection of economically important crop plants, increasing the capacity of seeds to express their vital functions, and improving their yields, particularly after selecting optimal and adequate doses of both adsorbent and adsorbate necessary for success in the adsorption process.

\section{ACKNOWLEDGMENTS}

The authors would like to extend their sincere appreciation to the Deanship of Scientific Research at King Saud University for supporting this research project.

\section{CONFLICTS OF INTEREST}

The authors declare no conflict of interest.

\section{REFERENCES}

Abdelhaliem E, Abdullah H and AL-Huqail AA (2013). Oxidative damage and mutagenic potency of fast neutron and UV-B radiation in pollen mother cells and seed yield of Vicia faba L. BioMed. Res. Int. 2013: 824656.

Abdelhaliem E and Al-Huqail AA (2016). Detection of protein and DNA damage induced by elevated carbon dioxide and ozone in Triticum aestivum L. using biomarker and comet assay. Genet. Mol. Res. 15 (2): gmr.15028736.

Arumuganathan K and Earle ED (1991). Estimation of Nuclear DNA Content of Plants by Flow Cytometry. Plant Mol. Biol. Rep. 9(3): 229-233.

Bhat T, Ansari MY, Choudhary S, Aslam R, et al. (2011). Synergistic cytotoxic stress and DNA damage in clover (Trifolium repens) exposed to heavy metal soil from automobile refining shops in Kashmir-Himalaya. ISRN Toxicol. 2011: 109092.

Blanco A, Salazar MJ, Cid CV and Pignata ML (2017). Accumulation of lead and associated metals (Cu and $\mathrm{Zn})$ at different growth stages of soybean crops in lead-contaminated soils: food security and crop quality implications. Environ. Earth Sci. 76: 182.

Bok-Badura J, Jakóbik-Kolon A, Karoń K and Mitko K (2018). Sorption studies of heavy metal ions on pectin-nanotitanium dioxide composite adsorbent. Sep. Sci. Technol. 53 (7): 1034-1044. 
Dhakshanamoorthy D, Selvaraj R and Chidambaram AL (2011). Induced mutagenesis in Jatropha curcas L. using gamma rays and detection of DNA polymorphism through RAPD marker. C. R. Biol. 334(1): 24-30.

Dolatabadi A, Sani1 B and Moaveni1 P (2015). Impact of nanosized titanium dioxide on agronomical and physiological characteristics of annual medic (Medicago scutellata L.). Cercet. agron. Mold. 48 (3): 53-61.

Dolezel J, Bartos J, Voglmayr H and Greilhuber J (2003). Nuclear DNA content and genome size of trout and human. Cytom. A. 51A (2): 127-128.

Feizi H, Kamali M, Jafari L and Moghaddam PR (2013). Phytotoxicity and stimulatory impacts of nanosized and bulk titanium dioxide on fennel (Foeniculum vulgare Mill). Chemosphere. 91: 506-511.

Gao F, Hong F, Liu C, Zheng L, et al. (2006). Mechanism of nano-anatase $\mathrm{TiO}_{2}$ on promoting photosynthetic carbon reaction of spinach. Biol. Trace Elem. Res. 111(1-3): 239-253.

Iqbal M, Abbas M, Nisar J, Nazir A, et al. (2019). Bioassays based on higher plants as excellent dosimeters for ecotoxicity monitoring: A review. Chem. Int. (CI). 5(1): 1-80.

Kole C., Kole P, Randunu KM, Choudhary P, et al. (2013). Nanobiotechnology can boost crop production and quality: first evidence from increased plant biomass, fruit yield and phytomedicine content in bitter melon (Momordica charantia). BMC Biotechnol. 13: 37-46.

Lyu S, Wei X, Chen J, Wang C, et al. (2017). Titanium as a Beneficial Element for Crop Production. Front. Plant Sci. 8: 597-610.

Maluszynska J and Juchimiuk J (2005). Plant genotoxicity: a molecular cytogenetic approach in plant bioassays. Arh Hig Rada Toksikol. 56: 177-184.

Marchiol L, Mattiello A, Pošćić F, Fellet G, et al. (2016). Changes in physiological and agronomical parameters of barley (Hordeum vulgare) exposed to cerium and titanium dioxide nanoparticles. Int. J. Environ. Res. Public Health. 13(3): 332-349.

Mishra A and Choudhuri MA (1999). Monitoring of phytotoxicity of lead and mercury from germination and early seedling growth indices in two rice cultivars. Water Air Soil Pollut. 114: 339-346.

Mittler R (2017). ROS are good. Trends Plant Sci. 22: 11-19.

Monteiro MS, Rodriguez E, Loureiro J, Mann RM, et al. (2010). Flow cytometric assessment of Cd genotoxicity in three plants with different metal accumulation and detoxification capacities. Ecotoxicol. Environ. Saf. 73: 1231-1237.

Nas FS and Ali M (2018). The effect of lead on plants in terms of growing and biochemical parameters: a review. MOJ Eco. Environ. Sci. 3(4): 265-268.

Oladele EO, Odeigah PGC, Taiwo IA and Yahay T (2014). The genotoxic effect of lead and zinc on cowpea (Vigna unguiculata) and maize (Zea mays Linn.). Ife. J. Sci. 16 (1): 143-148.

Pal S (2016). Detection of Environmental Contaminants by RAPD Method. I IJCMAS. 5(8): 553-557.

Pena ME, Korfiatis GP, Patel M, Lippincott L, et al. (2005). Adsorption of As (V) and As (III) by nanocrystalline titanium dioxide. Water Res. 39: 2327-2337.

Pourrut B, Shahid M, Dumat C, Winterton P, et al. (2011). Lead Uptake, Toxicity, and Detoxification in Plants. Rev. Environ. Contam. T. 213: 113-136.

Poursani AS, Nilchi A, Hassani A, Shariat SM, et al. (2016). The Synthesis of Nano TiO2 and Its Use for Removal of Lead Ions from Aqueous Solution. JWRP. 8: 438-448.

Rodriguez E, Azevedo R, Fernandes P and Santos S (2011). Cr (VI) Induces DNA Damage, Cell Cycle Arrest and Polyploidization: A Flow Cytometric and Comet Assay Study in Pisum sativum. Chem. Res. Toxicol. 24(7): 10401047.

Ruffini Castiglione M, Giorgetti L, Geri C and Cremonini R (2011). The effects of nano- $\mathrm{TiO}_{2}$ on seed germination, development and mitosis of root tip cells of Vicia narbonensis L. and Zea mays L. J. Nanopart. Res. 13: 2443-2449.

Ruffini-Castiglione M, Giorgetti L, Cremonini R, Bottega S, et al. (2014). Impact of $\mathrm{TiO}_{2}$ nanoparticles on Vicia narbonensis L. Potential toxicity effects. Protoplasma. 251: 1471-1479.

Sliwinska E, Bassel GW and Bewley JD (2009). Germination of Arabidopsis thaliana seeds is not completed as a result of elongation of the radicle but of the adjacent transition zone and lower hypocotyl. J. Exp. Bot. 60: 3587-3594.

Tosun F and Koyuncu F (2007). Investigations of suitable pollinator for 0900 Ziraat sweet cherry cv.: pollen performance tests, germination tests, and germination procedures, in vitro and in vivo pollinations. AGRIS. 34(2): 47-53.

Vashisth A and Nagarajan S (2010). Effect on germination and early growth characteristics in sunflower (Helianthus annuus) seeds exposed to static magnetic field. J. Plant Physiol. 167: 149-156.

Vig BK (1982). Soybean (Glycine max [L.] Merrill) as a short-term assay for study of environmental mutagens. Mutat. Res. 99: 339-347.

Visser T, Devrise, DP, Welles GWH and Scheurink JAM (1977). Hybrid tea Rosa polle .I. germination and storage. Euphytica. 26: 721-728.

Yang WW, Miao AJ and Yang LY (2012). $\mathrm{Cd}^{2+}$ Toxicity to a Green Alga Chlamydomonas reinhardtii as Influenced by Its Adsorption on TiO2 Engineered Nanoparticles. PLoS One. 7(3): e32300. 